\title{
Student Perceptions of Online Learning with Google Classroom during Covid-19 Pandemic
}

\author{
Rintis Rizkia Pangestika ${ }^{1}$, Nur Ngazizah ${ }^{2}$, Suyoto $^{3}$, Farah Farri Santhi ${ }^{4}$ \\ \{rintisrizkia@gmail.com ${ }^{1}$ \}
}

Primary Teacher of Education, Purworejo Muhammadiyah of University, Purworejo, Indonesia ${ }^{1,2,3,4}$

\begin{abstract}
The Covid-19 pandemic is a worldwide event of the spread of the Sars-Cov-2 virus which has paralyzed human activities in all fields, including education. All students study at home by doing distance learning or online learning (online). One platform that is affordable for all people is google classroom. Google classrooms provide supporting facilities to carry out online learning during the Covid-19 pandemic. The study was conducted to assess student perceptions of the online learning process using google classrooms during a pandemic in Covid-19. The reason for this research is that students' perceptions of online learning have never been researched in the middle of Covid-19. This research can be used as a reference in future learning if the Covid-19 pandemic continues. The research method used is descriptive quantitative with a questionnaire instrument. The results of the study show that the majority of students, namely more than $50 \%$, feel that online learning using google classrooms during Covid-19 pandemic can streamline learning, foster student independent learning initiatives, foster student interest in learning, and flexibility and efficiency of good time so that learning still running smoothly even though it is done remotely.
\end{abstract}

Keywords: Online learning, google classroom, the covid-19 pandemic

\section{Introduction}

In the present era of Revolution 4.0, the Internet is well known to the Indonesian people. Nearly all areas of human life make use of the Internet, particularly in the technology field in order to meet daily needs. The results from the 2016 Survey by the Indonesian Internet Network Providers Association (APJII) indicate that in Indonesia, internet users were 132,7 million with a total population of Indonesia of 256,2 million, i.e. 51,8\% [1]. Ease of internet access is one of the cultures of society that is shifting to the digital era. Technology and education are two things that cannot be separated, because they must go hand in hand. Therefore, the world of education has also shifted to the digital era, namely through educational actors such as lecturers, students, and human resources related to education using the internet network for the purposes of carrying out tasks such as teaching, doing college assignments, and doing other administration Therefore, as an educator who has an important position in changing this condition, he must be able to act as an agent of change by conducting distance learning that utilizes the internet network.

During Covid-19 pandemic, distance learning is very appropriate to apply. This is because the covid-19 pandemic has paralyzed human activities around the world, even in the field of education. All educational institutions are required to undertake distance learning by making use of the available facilities. So, the presence of an internet network system is needed to carry out distance learning. The educational world calls it online (online) or e-learning. Online 
learning is a form of internet use that can enhance students' role in learning [2]. Online learning cannot be used without supporting facilities, namely a platform. Google Classroom is one of the platforms that can be used. Google Classroom is a Google internet-based service that is useful for online learning. Google classroom's advantages include: a) easy set-up, which means teachers can add students, or share class codes directly to join b) save time, teachers can create, check, and place grades quickly. c) Google Classroom is affordable, free of advertising [3].

Then, according to previous research carried out by Saifuddin [2], which showed that 98.8 percent of students knew e-learning, 86.3 percent supported e-learning and 77 percent welcomed the use of e-learning. Furthermore, it made the perceptions of e-learning useful for students, could increase motivation, make material easier to understand, and help them to be ready for lectures. However, no previous research has been conducted into e-learning in the Covid-19 pandemic with Google Classroom. Research is therefore required into student perceptions of Google Classroom online learning during Covid-19. This study aims to determine the perception of the students of the online learning process in pandemic conditions using the Google Classroom platform. Where students have to be at home or not to leave the house, the conditions are different from the normal ones.

Research conducted by Zhafira [4] has led to a greater comfort in using the WhatsApp application and google classroom for 165 students from the Millennial group, based on their age. Students can learn new things with online learning activities that they may not have previously planned. Moreover, most students have a visual style which is more directed to image, writing or photography media. This concerns student habits in daily activities and conventional classrooms, where lecture material is distributed to the students via power points, presentations using diagrams, or by reading from teacher guides.

In addition, Anhusadar's research [5] has led to findings, namely the usual place to study for 60 students, 53 to 88.3 percent of whom have responded at home, 2 students or 3.3 percent who have responded in the garden, and 5 or 8.3 percent who have a good internet connection at home. Cell phones and laptops are students who use electronic devices for online lectures. Applications preferred by 56 students or $91.8 \%$ of students to participate in online lectures choose from Whatspp Group Application, 4 students or $6.5 \%$ of students choose the Zoom Application, and 1 or $1.6 \%$ of students choose the e-mail Application. When students are asked how well the material presented by online lectures can be understood by student as much as 1 student has responded well, 23 students have responded well, 34 students have sometimes replied, and up to 4 students have not been understood.

Research by Nurfalah (2019), then showed the important impact of the Google Class feature on learning in the era of the Industrial Revolution 4.0 including: (1) learning is done online using technology; (2) learning is not limited to space and time; (1) students are directly involved in the internet-enabling learning process; (4) learning material is easily accessible. (5) Educators can easily make Google classrooms to make learning efficient and efficient. The study was conducted to assess student perceptions of the online learning process using google classrooms during a pandemic in Covid-19.

\section{Method}

The method used in this study is a descriptive method of quantitative research. The objective of quantitative descriptive research is to explain and summarize different conditions according to what happened [7]. This study analyzes the perception of students' learning 
responses using the Google Classroom blended learning method during the Covid-19 pandemic. The tool used was a student answer questionnaire by Google. PGSD students were the subjects or respondents in semesters 2, 4 and 6 at Purworejo University Muhammadiyah, totaling 228 students.

This research was carried out by creating a class in Google Classroom, distributing the class code to students to join. Furthermore, all lecture components such as attendance, material, assignments, quizzes, UTS, and UAS can be carried out online in Google Classroom. Response questionnaires are given to students after participating in learning using Google Classroom. The result is a category of perception, namely supporting (positive), rejecting (negative), and neutral [8]. The perception response questionnaire consisted of two variables, namely measuring students' perceptions of the blended learning method with Google Classroom and perceptions of the Covid-19 pandemic conditions. Furthermore, the collected data were analyzed using descriptive analysis techniques by calculating the percentage of each indicator. Then grouped based on perceptual indicators, then compile an interpretation of the results of the questionnaire data processing and conclude the research results.

\section{Result and Discussion}

\subsection{Presenting the results}

Questionnaire data in the form of students' perceptual responses to online learning using google classroom during Covid-19 pandemic can be seen in Table 1 below.

Table 1. Questionnaire recapitulation of student perception responses to online learning using google classroom

\begin{tabular}{lcccc}
\hline \multicolumn{1}{c}{ Indicator } & \multicolumn{4}{c}{ Percentage (\%) } \\
& SD & D & A & SA \\
\hline The effectiveness of learning amid the Covid-19 & 5,1 & 10,6 & 65,6 & 18,7 \\
Pandemic & & & & \\
Promote independent student learning initiatives & 3,6 & 7,0 & 59,2 & 30,2 \\
Fostering student interest in learning & 4,1 & 6,3 & 64,5 & 25,2 \\
Flexibility and efficiency of learning time & 5,4 & 9,0 & 50,3 & 35,2 \\
\hline Average Score & 4,5 & 8,2 & 59,9 & 27,3 \\
\hline
\end{tabular}

On the basis of Table 1, it is possible that online learning with the Google Classrooms during Covid-19 pandemic can have a strongly agreed $18.7 \%$ on the pandemic. $65.6 \%$ disagree, $10.6 \%$ disagree and $5.1 \%$ strongly disagree. Thus, it can be concluded that according to the perceptions of students, online learning with Google classrooms during Covid-19 has a positive impact, as demonstrated in the $65.6 \%$ agreement and $18.7 \%$ strong support, or $84.3 \%$ of students agree that online learning in Google school is effectively implemented during the Covid-19 pandemic.

Moreover, on the basis of Table 1 the second indicator shows that $32.2 \%$ and $59.8 \%$ of students strongly agree that online learning through google classrooms in the Covid-19 epidemic has a positive impact. Then, online learning in the Google classroom during the Covid-19 pandemic may also encourage student interest in learning, which is shown in Table 1. 25.2\% and $64.5 \%$ of students agree strongly and agree with each other. In addition, online learning 
with Google Classrooms is more flexible and effective in terms of time during the Covid-19 pandemic, so that the learning can be carried out in accordance with mutual agreements and regulations at any time. On the basis of the research results described, most students, more than 50 percent, believe that Google on-line learning during the Covid-19 pandemic can simplify learning, promote self-study, encourage student interest and flexibility and time efficiency. Good so that learning goes smoothly even if it is done remotely.

\subsection{Create a discussion}

Based on the results of the research described above, the use of google classrooms during Covid-19 pandemic makes students actively ask questions through the provided comment column facility. This can be seen in students who are embarrassed to ask questions directly and can be facilitated properly by the comments column, because they do not feel embarrassed when asking online through the comments column. This can be seen in the comments column in the google classroom where more than 100 comments occurred during the learning process through google classroom for one meeting. This shows that google classroom can increase interaction in the learning process. This is in line with Lin, et al. (2017) and Borba, et al. (2016) who stated in their research that Blended Learning, in which online learning contains learning, can increase interaction between lecturers and students [9][10].

In addition, online learning with google classrooms during Covid-19 pandemic can be said to be effective because all material can be delivered efficiently and learning objectives can be achieved. It is said to be effective because students can re-study the material at another time and anywhere as long as there is a network. Thus in terms of time efficient and flexible implementation. This is in line with Yodha (2019) who argues based on the results of his research that students are enthusiastic about doing online learning. This is indicated by the existence of facilities that are in accordance with the concept of online learning, namely using technology and network-based. Students' enthusiasm in learning is supported by the presence of facilitators or lecturers to support online learning [11]. So that the materials and assignments given are easy to access anywhere and anytime. The collection of tasks is more efficient and faster and is neatly structured so that task work becomes effective and efficient because it is done online. In addition, Oka (2019) also stated that based on the results of his research, the development of online course materials with google classroom-based virtual classes could be implemented to enrich the strategy for delivering lecture materials and to create an open and flexible learning environment. A learning environment that can be accessed from anywhere, anytime and by anyone [12]. Furthermore, based on research results by Bowyer \& Chambers (2017), it shows that there are three advantages to using the Blended Learning model, namely in terms of improving learning outcomes, time effectiveness in learning, and accommodating the online discussion process [13]. So it can be said that with the covid-19 pandemic, which requires all students to study at home, learning can be done remotely, namely online using google classroom. However, there are several obstacles that occur in the implementation, namely the stability of the internet network signal which is not evenly distributed throughout the region, resulting in some students who find it difficult to reach the signal so that they can participate in online learning properly. However, this can be overcome with material in the form of video or in pdf format so that it can be opened and studied at any time. 


\section{Conclusion}

The results showed that the majority of students agreed that online learning using google classrooms during Covid-19 pandemic could streamline learning, foster student independent learning initiatives, foster student interest in learning, and flexibility and good time efficiency so that learning runs smoothly even though it is carried out continuously. long distance. Based on the conclusions obtained, online learning using google classroom can be used as a reference for educators who have never done online learning. Because the google classroom platform can be accessed by anyone and does not really need a large internet quota, so it is affordable for those with signal difficulties or limited internet quota. For researchers who want to carry out further research related to the use of google classrooms during Covid-19 pandemic, they can try it by comparing it with other platforms that are available for free.

\section{Acknowledgements}

This article is the outcome of independent research. I would like to thank students who have helped in conducting research, not to forget that I would also like to thank the Muhammadiyah University of Purworejo for funding the output of this article at BISMAS UNIMMA 2020.

\section{References}

[1] A. P. J. I. Indonesia, "Penetrasi dan Perilaku Pengguna Internet Indonesia," 2016. doi: 10.5151/cidi2017-060.

[2] M. F. Saifuddin, "E-Learning dalam Persepsi Mahasiswa," J. VARIDIKA, vol. 29, no. 2, pp. 102 109, 2018, doi: 10.23917/varidika.v29i2.5637.

[3] D. Pratama and H. Sopryadi, "Pengaruh Pemanfaatan Kelas Elektronik Terhadap Efektifitas dan Efisiensi Proses Belajar STMIK XYZ," Jatisi, vol. 3, no. 1, pp. 61-72, 2016.

[4] N. H. Zhafira, Y. Ertika, and Chairiyaton, "Persepsi Mahasiswa Terhadap Perkuliahan Daring Sebagai Sarana Pembelajaran Selama Masa Karantina Covid-19,” J. Bisnis dan Kaji. Strateg. Manaj., vol. 4, pp. 37-45, 2020.

[5] L. Anhusadar, "Persepsi Mahasiswa PIAUD terhadap Kuliah Online di Masa Pandemi Covid 19," KINDERGARTEN J. Islam. Early Child. Educ., vol. 3, no. 1, p. 44, 2020, doi: 10.24014/kjiece.v3i1.9609.

[6] E. Nurfalah, "Optimalisasi E-Learning berbasis Virtual Class dengan Google Classroom sebagai Media Pembelajaran Fisika," Phys. Educ. Res. J., vol. 1, no. 1, p. 46, 2019, doi: 10.21580/perj.2019.1.1.3977.

[7] B. Bungin, Metode Penelitian Kuntitatif: Komunikasi, Ekonomi, dan Kebijakan Publik serta Ilmuilmu lainnya, Edisi Kedua (2nd ed.). Jakarta: Kencana Prenama Media Group, 2011.

[8] N. Sudjana, Penilaian Hasil Proses Belajar Mengajar. Bandung: PT Remaja Rosdakarya, 2012.

[9] Y. W. Lin, C. L. Tseng, and P. J. Chiang, "The effect of blended learning in mathematics course," Eurasia J. Math. Sci. Technol. Educ., vol. 13, no. 3, pp. 741-770, 2017, doi: 10.12973/eurasia.2017.00641a.

[10] M. C. Borba, P. Askar, J. Engelbrecht, G. Gadanidis, S. Llinares, and M. S. Aguilar, "Blended learning, e-learning and mobile learning in mathematics education," ZDM - Math. Educ., vol. 48, no. 5, pp. 589-610, 2016, doi: 10.1007/s11858-016-0798-4.

[11] S. Yodha, Z. Abidin, and E. Adi, "Persepsi Mahasiswa Terhadap Pelaksanaan E-Learning Dalam Mata Kuliah Manajemen Sistem Informasi Mahasiswa Jurusan Teknologi Pendidikan Universitas 
Negeri Malang,” J. Kaji. Teknol. Pendidik., vol. 2, no. 3, pp. 181-187, 2019, doi: 10.17977/um038v2i32019p181.

[12] G. P. A. Oka, "Persepsi Mahasiswa STKIP Citra Bakti Terhadap Kelas Virtual Berbasis Google Classroom," Imedtech, vol. 3, no. 1, pp. 85-95, 2019, [Online]. Available: https://core.ac.uk/download/pdf/211833861.pdf.

[13] J. Bowyer and L. Chambers, "Evaluating Blended Learning (1)," pp. 17-26, 2017. 